\section{REFERENCES}

Alexander, L. L. and Harrington, L. A. (1955): Multiple Arteriovenous Fistulas of Lung, N.Y. St. J. Med., 55, 2807.

APTHORP, G. H. and BATES, D. V. (1957): Report of a Case of Pulmonary Telangiectasia, Thorax, 12, 65 .

Cooley, D. A. and McNamara, D. G. (1954): Pulmonary Telangiectasia: Report of a Case Proved by Pulmonary Biopsy, J. thorac. Surg., 27, 614.

DE GRUCHY, G. C. (1960): "Clinical Haematology in Medical Practice," Oxford: Blackwell Scientific Publications.

Hodgson, C. H., Burchell, H. B., Good, C. A. and ClageTt, O. T. (1959): Hereditary Haemorrhagic Telangiectasia and Pulmonary Arteriovenous Fistula: Survey of a Large Family, New Engl. J. Med., 261, 625.

Hodgson, C. H. and KAYE, R. L. (1963): Pulmonary Arteriovenous Fistula and Hereditary Haemorrhagic Telangiectasia: A Review and Report of 35 Cases of Fistula, Dis. Chest, 43, 449.

Koch, H. J. JR., Escher, G. C. and Lewis, J. S. (1952):
Hormonal Management of Hereditary Haemorrhagic Telangiectasia, J. Amer. med. Ass., 149, 1376.

LE Roux, B. T. (1959): Pulmonary Arteriovenous Fistulae, Quart. J. med., 28, 1.

MOYER, J. H., Glantz, G. and BREST, A. N. (1962): Pulmonary Arteriovenous Fistulas: Physiologic and Clinical Considerations, Amer. J. Med., 32, 417.

OsLER, W. (1901): Family Form of Recurring Epistaxis, Associated with Multiple Telangiectases of the Skin and Mucous Membranes, Bull. Johns Hopk. Hosp., 12, 333.

Rendu, M. (1896): Epistaxis Répétées Chez un Sujet Porteur de Petits Angiomes Cutanés et Muqueux, Gaz. Hop. (Paris), 1322.

WEBER, F. P. (1907): Multiple Hereditary Developmental Angiomata (Telangiectases) of the Skin and Mucous Membranes Associated with Recurring Haemorrhages, Lancet, ii, 160.

WHITAKER, W. (1947): Cavernous Haemangioma of Lung, Thorax, 2, 58.

WiLLIS, R. A. (1962): "The Borderland of Embryology and Pathology." London: Butterworth.

\title{
THIAZIDE DIABETES
}

\author{
E. L. Harris, M.B., M.R.C.P., M.R.C.P.(Ed.) \\ R. O. F. HaRdwick, M.B., M.R.C.P. \\ Diabetic Clinic, West Kent Hospital, Maidstone.
}

IN 1959 the first reports of impairment of carbohydrate metabolism by benzothiadiazine appeared in the medical press (Wilkins, 1959; Freis, 1959; Finnerty, 1959). Since then there have been further reports of diabetes secondary to these drugs (Suger, 1961; Dollery, Pentecost and Samaan, 1962; and Samaan, Dollery and Fraser, 1963). Shapiro, Benedek and Small (1961) described five cases of "thiazide diabetes" which was characterised by delayed onset in elderly patients, manifested primarily by hyperglycaemia but without acidosis, controlled readily with insulin, and eventually reversible. Goldner, Zarowitz and Aksun (1960) confirmed the reversibility of the condition: although Samaan and others (1963) found a lessening in severity of the diabetic state after discontinuation of therapy, they had not at that time observed a full remission. A fatal case of diabetic coma (Cranston, Juel-Jensen, Semmence, Handfield, Forbes and Mutch, 1963) supported the findings of other workers that ketoacidosis was usually absent in this type of diabetes. However, Sugar (1961) reported the occurrence of diabetic acidosis in two pregnant women after chlorothiazide therapy.

It was initially suggested that thiazide-induced diabetes only occurred in "potential diabetes" or in prediabetic subjects. Potential diabetes is considered as such when subjects have a glucose tolerance curve with peaks at $180 \mathrm{mg} . / 100 \mathrm{ml}$. or above, one hour after a standard glucose load (Shapiro and others, 1961), and pre-diabetes is defined as that in individuals who have a family history of diabetes, fasting glucose levels repeatedly above $100 \mathrm{mg} . / 100 \mathrm{ml}$. and abnormal glucose tolerance tests, the criteria of which require that the blood glucose level was over $160 \mathrm{mg} . / 100 \mathrm{ml}$. in one hour or over $110 \mathrm{mg} . / 100 \mathrm{ml}$. in two hours (Mustala and Toivonen, 1965). Later it became evident that hyperglycaemic effects could be produced in "normal" subjects who fell outside this definition. The absence of ketoacidosis has been an interesting feature in some of the cases especially where high blood glucose levels were found.

We describe the first reported case of diabetes induced by cyclopenthiazide (as Navidrex K) in a "normal" subject who has made a full recovery.

\section{Case Report}

A 57-year-old male school-teacher whose normal weight is $170 \mathrm{lbs}$. was first seen by his general practitioner in December 1964, when he complained of blurring of vision because of difficulty in focusing his eyes.

On examination the important finding was a mild hypertension of $190 / 110 \mathrm{~mm}$. Hg. with Grade 2 retinopathy. His urine was free of albumin and sugar. Treatment was commenced with methyldopa $250 \mathrm{mg}$. b.d. and Navidrex K tabs 1 b.d. By February 1965 his blood pressure had fallen to $170 / 100$ and he felt very much better.

On 21st April he was admitted to hospital with a history of urinary frequency, excessive thirst, progressive weakness and drowsiness for two weeks, and for two days 
he could not walk and was confined to bed. He had run out of all medication two weeks previously. There was no family history of diabetes.

On examination a well nourished slightly dehydrated male. Height 5 feet 8 inches. His breath smelt strongly of acetone and the following were the relevant findings present: Pulse 96/minute regular, B.P. 90/60 mm. Hg., Soft apical systolic murmur, Respiration: Rate 16/ minute, typical acidotic breathing, Semi-conscious but could be roused. No localising signs. Fundi: Grade 2 hypertensive retinopathy.

Investigations: Urine, SG 1020, Sugar 2\%, Acetone strongly positive. Blood sugar, $886 \mathrm{mg} . / 100 \mathrm{ml}$. Modified method of Folin and Wu (venous blood). Blood urea, $118 \mathrm{mg} . / 100 \mathrm{ml}$. Serum sodium, $145 \mathrm{mEq} / \mathrm{l}$. Potassium, $4.3 \mathrm{mEq} / \mathrm{l}$. Chloride, $108 \mathrm{mEq} / \mathrm{l} . \mathrm{CO}_{2}, 36.3 \mathrm{mEq} / \mathrm{l}$. $\mathrm{Hb}, 17.4 \mathrm{~g} . / \mathrm{ml}$. PCV $52 \%$. WBC, $19,900 / \mathrm{cu} . \mathrm{mm}$. Neutros $80 \%$, monos $1 \%$, lymphs $19 \%$. Chest X-ray, heart size within normal limits, aorta somewhat unfolded, the lungs appeared clear.

Treatment: He was treated by rehydration and fourhourly doses of soluble insulin, requiring 110 units on the day of admission, and eventually was satisfactorily controlled on Lente Insulin 60 units and a 2,000 calorie diet. Three days after admission his blood sugar two hours after a meal was $107 \mathrm{mg} . / 100 \mathrm{~m}$ !. and his blood urea had fallen to 55. Two weeks later he was discharged from hospital on Lente Insulin 52 units daily.

Progress: One month after admission: Well, but because of frequent attacks of hypoglycaemia his insulin requirement dropped to 44 units daily. Two months after: On 12 units per day only and all urine tests sugar free.

Three months after: Insulin discontinued and 10 days later a two-hour post prandial blood sugar was 88 mg./100ml. Urine sugar free. Five months later: Well. Urine sugar free. BP $165 / 110$.

Eleven months later: Well. BP 170/110. Blood urea $35 \mathrm{mg} . / 100 \mathrm{ml}$.

Glucose tolerance curve using Nelson and Somogyi's micro method for estimating blood (venous) glucose: Urine-sugar Acetone

Fasting blood glucose

$\frac{1}{2}$ hour after glucose

1 hour after glucose

$1 \frac{1}{2}$ hours after glucose

2 hours after glucose

$87 \mathrm{mg}$
$150 \mathrm{mg}$
$144 \mathrm{mg}$
$144 \mathrm{mg}$
$93 \mathrm{mg}$

Urine-sugar Acetone

Normal fasting blood glucose range is $50-90 / 100 \mathrm{ml}$. blood.

Fourteen months later: Well. Blood pressure 160/95 on methyodopa $250 \mathrm{mg}$ t.d.s. No glycosuria.

\section{Discussion}

This is the first reported case of diabetes induced by cyclopenthiazide. His presentation was not typical of the reported cases of benzothiadiazine-induced diabetes in that he had a fairly marked degree of ketoacidosis when he was admitted in diabetic coma. We have classified this man as "normal" because he has no family history of diabetes, his glucose tolerance test is normal and over 14 months he has had no glycosuria.
His emotional state has prevented us from carrying out further tests. The patient received a potassium supplement of $1-2 \mathrm{~g}$. potassium chloride daily and it is $C$ interesting to speculate whether this had the effect of $\overrightarrow{\bar{F}}$ delaying the onset of his symptoms in view of the work of Wolff and Parmley (1963) when they observed that the hyperglycaemia induced by thiazide diuretics could be nullified by the administration of large doses of potassium chloride (750 mg./Kg.), and of Rapoport and Hurd (1964) who observed that the adverse effect of chlorothiazide on glucose tolerance could be significantly improved in man with potassium supplements $(4.5 \mathrm{~g}$. daily).

\section{Summary}

A case of cyclopenthiazide-induced diabetes with full remission is reported.

\section{REFERENCES}

ANNINo, J. S. (1965): Nelson \& Somogyi Method for Blood Glucose Determination. Clinical Chemistry, Principles and Procedures, 3rd Ed., p. 135 Boston: Little, Brown.

Cranston, W. I., Juel-Jensen, B. E., Semmence, A. M., HANDField, R. P. C., Forbes, J. A., and MUTCH, L. M. M. (1963): Effects of Oral Diuretics on Raised Arterial Pressure, Lancet, ii, 966.

Dollery, C. T., Pentecost, B. L., and SamaAn, N. A. (1962): Drug-induced Diabetes, Lancet, ii, 735.

FreIS, E. D. (1959): in 'Symposium on Hypertensive Disease' ed. J. H. Moyer, p. 653, Philadelphia: W. B. Saunders.

FinNeRTY, F. A. (1959): in 'Symposium on Hypertensive Disease', ed. J. H. Moyer, p. 653, Philadelphia: W. B. Saunders.

Goldner, M. G., Zarowitz, H. and Aksun, S. (1960): Hyperglycemia and Glycosuria due to Thiazide Derivatives Administered in Diabetes Mellitus. New Engl. J. Med., 262, 403.

Mustala, O., and Toivonen, S. (1965): Comparison of the Diabetogenic Effects of Chlorothiazide and Furosemide, Ann. Med. Fenn., 54, 75.

RAPOPORT, M. I., and HuRD, H. F. (1964): ThiazideInduced Glucose Intolerance Treated with Potassium, Arch. intern. Med., 113, 405.

SamaAn, N., Dollery, C. T. and Fraser, R. (1963): Diabetogenic Action of Benzothiadiazines. Seruminsulin-like Activity in Diabetes Worsened or Precipitated by Thiazide Diuretics, Lancet, ii, 1244.

Shapiro, A. P., BenedeK, T. G., and Small, J. L. (1961): Effect of Thiazides on Carbohydrate Metabolism in Patients with Hypertension, New Engl. J. Med., 265, 1028.

SugAR, S. J. N. (1961): Diabetic Acidosis During Chlorothiazide Therapy, J. Amer. med. Ass., 175, 618.

WILKINS, R. W. (1959): New Drugs for Treatment of Hypertension, Ann. intern. Med., 50, 1.

WolfF, F. W., and Parmley, W. W. (1963): Aetiological Factors in Benzothiadiazine Hyperglycaemia, Lancet, ii, 69. 